\title{
On English Learning Anxiety and Its Affective Factors of College Students
}

\author{
Wang Zhen \\ School of Foreign Languages \\ Jiangxi Science \& Technology Normal University \\ Nanchang, China
}

\author{
He Jianbo \\ School of Tourism \\ Jiangxi Science \& Technology Normal University \\ Nanchang, China
}

\begin{abstract}
Through discussing the definitions and causes of anxiety, analyzing the causes of college students' English learning anxiety from the source, the thesis sums up the present circumstance of college students' English learning anxiety at home and abroad. The reason of anxiety is made up of objective environmental causes and emotional factors. The objective environmental causes include family environment, comprehensive quality of teachers, exam-oriented education, ways of teaching and learning activity and so on. Emotional factors include character weakness, self-confidence insufficiency, unease mood and so on. Then coping strategies are put forward for college students' anxiety. In the end, there is a conclusion that eliminating college students' anxiety in English learning is apparently an important project.
\end{abstract}

Keywords-English learning anxiety; College students; Objective environmental factors; Subjective emotional factors

\section{INTRODUCTION}

\section{A. Research on Situation at Home and Abroad}

Today, many foreign researchers have paid attention to the impact of learning motive, learning effect, gender on the anxiety, such as Horwitz and Bailey through experimental study concluded that there is a negative correlation between anxiety and effect of learning, Horwitz had done a lot of work, formed his own theory, and designed a scale named Foreign Language Classroom Anxiety Scale(FLCAS) on the basis of the theory to evaluate foreign language anxiety Erving Goffman, Penelope and Sally Mcconnell Ginet studied the influence of gender on foreign language learning. Linguists Gardner and Clark, L.H think study motive is one of the main reasons affecting English learning anxiety.

Many domestic researchers study the English learning anxiety from the angle of the tests, don't consider the undergraduate. Li Xuemei mentioned in "how to help students overcome the English learning anxiety", Inappropriate teachers' teaching methods would let the students' generate anxiety. Meng Weina pointed out in "foreign language learning anxiety and the innovation ability training" that there exist many causes that have an impact on the behavior of students' learning foreign language, internal cause and external cause, such as wrong language learning attitude, lack of interest and perseverance, initiative to give up in trouble. Some undergraduates avoid teacher's method and think some teacher have poor foreign language level. Shang Jianguo did a survey from the influence of gender, the results of the survey show that Female college students' English learning anxiety is smaller than male college students. Cui Dan thought that low self evaluation and competitive consciousness are two important causes of English learning anxiety. Fu Xiaodan thought English learning anxiety is in connection with students' character.

\section{B. Significance of Study}

The causes of college students' English learning anxiety from the source are divided into objective environmental causes and personal causes. The objective environmental factors are the family environment, the comprehensive quality of teachers, the way of teaching, the form of learning and grades. Subjective emotional factors are character cowardice, lack of self-confidence, unease emotion and so on. Studying college students' English learning anxiety and analyzing the effective variables can not only help us find the primary causes for English learning anxiety, but also can help us put forward some coping strategies for the causes. In English teaching, on the one hand, the teacher plays a leading role, the teacher's words and deeds directly affects the student behavior. On the other hand, the study of college students English anxiety can give students some creative suggestions, which can give students a hand to reduce anxiety. Thus, it can help students develop the confidence to learn English well and reduce English learning anxiety. As a teacher should keep a watchful eye on English learning anxiety and try to help students overcome the fear mood in the teaching, which has important significance for improving college students' English learning and the level of English teaching.

\section{THE REASONS FOR ENGLISH LEARNING ANXIETY OF COLLEGE STUDENTS}

\section{A. Definition of Anxiety}

Anxiety is one of the emotional disorders, also known as spiritual abnormalities. Anxiety is defined as an spiritual state with fear which is produced when person is unable to achieve their expected aims or overcome the threat of obstacles.

Jane Arnold defined language anxiety as fear and worry; It is produced when students study English. This type of anxiety becomes the big resistance to teachers when they give. 
Learning anxiety isn't same as the general sense of anxiety, mainly refers to that when learners express in a foreign language or second language, they produce fear or anxiety psychology. It has a relationship with classroom language learning, beliefs and emotions complex are produced.

Learning anxiety is tension and fear (including talking, listening and learning) which has a special relationship and may be the largest emotional disorders. Anxiety may belong to mental state, may also be a spiritual quality. Anxiety, is produced when meeting a abnormal condition or event, this anxiety could disappear after some time. (Macintyre \& Gardner, 1994:284)

\section{B. Objective Environmental Factors}

\section{1) Teachers and Teaching Methods}

The survey of learning anxiety shows that $50 \%$ undergraduates are not satisfied with their teachers' teaching methods or foreign language level, the teacher's personality and the style of doing things, such as some teachers show favoritism. Many students accept the unfair because teacher shows partiality to the other students. Adversely, the undergraduates who don't get the teachers' attention, they think the teacher don't take them seriously, students will produce anxiety. Some teachers assess students by their own likes and dislikes. It is obvious that the undergraduate whom teachers dislike and pay attention to is not a bad student. But which will enhance ' their anxiety, defeat student's enthusiasm and self-confidence, cause students alienation or hostility, therefore directly affect the language learning effect.

In fact, Expressing thought in a foreign language is a kind of challenge for us, if teachers' teaching methods aren't proper, it will urge students to feel anxious. Ever the teacher always use the traditional teaching methods- explains and analysis of sentence composition, pronunciation. Teacher often uses grammar translation method in language teaching. Students can't think lively and truly learn, so the process of teaching knowledge becomes teacher-centered activity. We may think that students are seldom required to join in the process of study, they are passive, which will not cause students bigger pressure. However, it is harmful to learning English for a long time.

The reform of college English teaching requires the teaching goal changes from the training of reading and writing skills to cultivating undergraduates' listening and speaking skills, and places the exchange in the first place, this requires virtually bring more pressure to college students. If teacher can't create a loose, emotionally safe learning environment, it is bound to greatly increase the students' anxiety. The worse class behaviors will cause anxiety, the anxiety reacts on students class behaviors, producing a terrible circle.

\section{2) The Form of Learning Activity}

Cooperative learning is a new learning type. Many scholars put forward that cooperation team can make learners have a sense of belonging, can reduce the learner anxiety produced in the language communication activities, so that they show greater enthusiasm and creativity of learning. The teamwork among students is happy, which would reduce the learners' anxiety. If not, partners and students can't get along well. It can deepen learners' anxiety degree and form a new study pressure, which has the negative effect on language learning

\section{3) Multi-media Teaching Mode}

Multi-media teaching mode provided wealthy teaching resources, teaching content. Using the multi-media technology to translate the text, pictures of the materials, image, music, dialogue to intuitive form, create a real language environment. Teachers master students learning situation by in-class test Test frequency increases, however, the abundant teaching resources also brought various content, such as pressure, especially unit to pass the test of network autonomous learning, students can't pass the test who cannot enter the study of the next unit. These drain students' study energy, especially the summation evaluation of the final exam enlarge the learning anxiety of the students, most of the students worry about failing the exams, thus they must face retake course and makeup examination. Anxiety is from the fear of test. Appropriate anxiety is good for study and examination.

\section{4) Problems Left Over by History}

Before the students contact with the college, they have accepted basic education for English for six or eight years. The majority of the students have language foundation and study ability. But the level of each student is not same because each schools' teaching quality is different. This difference in English language learning in individual psychological anxiety would be comprehensive and lasting. This would exist the case that some students are bad at learning English and even don't like studying English. When they go to college, they are not willing to study English by themselves and don't know how to study. Some students with good grades are overconfident, they don't study English hard, and they live off their past gains. So to the end, most of the students will feel anxious when their teachers teach much more English knowledge.

\section{Subjective Personal Factors}

Effect is affected by a variety of emotional factors, students' introverted and extroverted personality characteristics, "self-esteem", "confidence" decide the students' classroom behavior to a great extent, students answer the question without confidence, timidity, shy and afraid of classmates laugh, teacher criticism. The investigation of undergraduates reflects that each student has the different level of anxiety.

\section{1) Autonomous Learning Ability}

Most undergraduate have no idea how to study by themselves. When students access to the university, they are ill grounded allotting their spare time. They don't have learning plan and aren't ignorant of the way of English learning. Undergraduates will attend class in line with school arrangement. If students are not clear about knowledge point, they aren't willing to make efforts to get it by their efforts after class. They spend most of their time in surfing online shop, playing with mobile, seeing the films and other playing. 


\section{2) Personality and Competitiveness}

Personality factor has a great influence on the behavior of language subject. Learners' personality more inclined to export-oriented, their linguistic behaviors' sensitivity and plasticity are better, the mood irritability is more positive, the oral expression ability raise faster. But there's also the study found that introverted learners have more chances of success in the development of language cognition than extroverted learners. Introverted learners are earnest people, they will take more time to write and read, so they can enjoy the pleasure of success. Introverted people and extroverted people don't have obstacles in the comprehensive ability of English. In English professional skills, listening comprehension and writing is basically not influenced by personality tendency, outgoing person has a larger advantage in dictation, introverted people has greater superiority in reading comprehension, vocabulary and grammar.

Although some students have bad scholastic attainment, they hope to study English well. When they compare themselves with other students who are better than them or their expected performance, they find someone better than themselves or think their performance are not idealistic, they will be agitated. High self assessment students often think that their aptitude in English is optimal. Thus they are glad to face the hardship in the learning. The low self-evaluation students doubt their intelligence. Students think their study is fruitless. No matter how they make efforts, they can't get good grades. Students delay manages these thoughts, even give up studying.

\section{3) Lack of Self-confidence}

The research shows that $30 \%$ students are shortage of selfconfidence and adventure spirit, because of his cowardice. They always don't raise their head and their eyes blinked. Their hearts speed up, sound is very small when they are called up by their teacher. Some students in severe cases will appear moist palms, voice tone sand-hi, teeth chattering phenomenon. Generally, when the emotion of worry affect students for long, student will begin to doubt them and be selfdenial. Students also choose to give up as long as they meet the difficulty in the English study. The reasons are that students consider they aren't able to understand it and they are afraid of asking their teacher and classmate. In the class, they always feel tired, and can't keep their attention for very long. They are frightened to open their mouth to practice English, because they are afraid that their teacher and classmates deny him when they are wrong.

\section{COPING STRATEGIES FOR ENGLISH LEARNING ANXIETY OF COLLEGE STUDENTS}

\section{A. What Should Language Teachers Do}

Each student is an individual, their thoughts and psychology doesn't reach mature. When teachers find out the students' foreign language worry, teachers should take action to help students reduce and overcome it, to create a lively, positive and uplifting, easing and joyful learning environment and help students build a sense of security, easily learn. I accessed to a large amount of data and summed up some methods used in contemporary language educators and some teachers' experience.

\section{1) Establish a Harmonious Relationship Between Teachers and Students}

Teaching is a process of interactive between teacher and students. It is necessary for teacher to know some psychological knowledge and master the rule of students' mental activity. First, teacher may make students feel you can light the fire in their hearts and can bring important influence to them. Teachers' humor, knowledge and friendly character can help teacher build a good impression on students. Second, teacher would get much insight into students and care for them Students would show more trust, as students opinions are respected, which can make students translate their love for English teachers into interest for learning English. Research shows that good relationship between teachers and students has a high positive correlation with learning effect.

Atmosphere during teaching is controlled by the teacher. Teacher's prejudice and inconsistent expectations will bring students psychological pressure and insecurity. Some students exist feared state of mind, students will feel worried, irritated, and so on, when they get touch with English class. Foreign language teachers as an organizer of teaching activities, should pay attention to students' emotional factors control. Most studies definitely pointed out that teachers' positive feedback, such as the proper way of encouraging, can arouse the enthusiasm of the students', reduce anxiety, promote the development of the relationship, form a friendly classroom atmosphere, raise the students' study efficiency. Teacher should take with undergraduates to understand their thought and help them to find out the gap and insufficiency of study, thus give them more encouragement. Students have their own thoughts though their thought may not be mature. As a teacher coming into students inner to translate their immature thought is very necessary.

When students make mistakes in the class, teacher shouldn't criticize students, but keep a tolerant attitude and correct their wrong in a euphemistic way. The use of tolerate open-minded attitude towards students reduces the students' language application of negative evaluation anxiety.

\section{2) Adopt Flexible Teaching Methods to Strengthen}

\section{Students' Self-confidence}

Students keep confident situation, they are brave in overcoming some problem which they meet in the process of language learning. While self-confidence training needs both students' own efforts and the help of teachers. Teachers skillfully use the advantages of each student, let them develop their strength in the proper chance. Exploring their own potential can help students establish self-confidence. Teachers provide feedback, including the way of talking with students, students' evaluation, teaching means, effect students' selfconfidence. Teachers shouldn't explain new knowledge throughout the class, teacher must have an interact with students who think they are poor students. Teacher may inquire these students to reply some simple problems for a special purpose and give them recognition and praise. For students who feel themselves inferior, the teacher can offer 
them more attention and encourage in study and life. Students will have strong desire to cooperate with foreign language teacher. Once students have learning motive, they can make a progress.

When students speak, teacher should listen with a smile, give them silent encouragement; When students have an idea for explain knowledge and creative opinion, teacher should give them timely praise, let them feel the joy of success; When they are wrong, the teacher should not say "NO" to completely deny, should see the correct part of its, small to a word, phrase, big to a sentence patterns. As long as there is the right place, teacher should give positive affirmation. Meanwhile teacher should use inspirational language to help them correct mistakes. Over time, confidence of students' English learning must be strengthened. Anxiety produced by the shortage of self-confidence will gradually ease.

\section{B. What Should Students Do}

In English teaching, for one thing, the teacher plays a leading role, the teacher's words and deeds directly affects the student behavior. Teachers can try their best to give a hand to students. For another thing, students are the subjectivity of learning. As a student, anxiety has become a big problem in English study; student can use these methods to help them to overcome this learning anxiety.

\section{1) Communicate with Classmates and Teacher}

It is helpful for students to spend time in communicating with the classmates about the feeling of study. By talking with classmates, students are aware of their classmates' feeling. If classmates have the same situation, you will feel better. Moreover, let teachers know your anxiety. Teacher was once students, so teachers can put themselves in students position and analysis the problem with you and give you a hand timely.

\section{2) Do Interesting Things and Make You Relax}

Students can do something to relieve anxiety, such as go for a walk, watch movies, listen to music and take part in some sports activities, these things are too numerous to list. Sometimes there is no point for students to think about many things in the classroom temporarily in order to relieve anxiety.

\section{3) See Yourself Correctly}

See yourself correctly. Students should think see their stronger points be objective about their advantages and disadvantages and don't lose self-confidence. Students must know their weakness and strength. Don't compared with other students, students don't feel bad, but students must require themselves to make progress. When getting a small achievement, students should give themselves encouragement timely.

If students attribute their success to internal reasons such as ability and hard work, it means they affirm themselves, which helps them to form a positive self-image. They will make efforts to study well. Some students owe their failure to low ability, students will think they are loss of the ability and deny themselves. It is easy to produce self-abased psychology and excessive anxiety. Therefore, students should owe their success to ability, fail to not enough effort, which will enhance the students' confidence and reduce anxiety.

\section{4) Practice English as much as Possible}

The study of English needs practice. English learning should be blended in students' life. Undergraduate can make use of internet to practice English and communicate with foreign friends and students who learn English well, watch English movie and the foreign new and so on. Watching English movies is not only an entertainment but also a good way to learn English and know about the culture of foreign countries.

\section{CONCLUSION}

A large number of studies have shown that anxiety is still common in college students' foreign language learning. But most of the researches in this field are in some special environment such as summer foreign language training classes, it ignores the anxiety for normal college students during the process of English learning. In view of this, this study intends to explore the affective variable for anxiety and ways to help college students. As constant attention research on the emotional factors in English study, teachers and learners pay more attention to English learning anxiety. English learning anxiety problem need teacher to play the correct guiding role. Teacher is able to arouse students' learning motive and interest as much as possible and use different teaching methods and means according to different individuals, improve the learners' competitive consciousness and ability, to ease the anxiety.

The results of this study show that the college students English learning anxiety is widespread, and is negatively related with their English achievement, namely the anxiety has side effects on English learning. The English anxiety is stronger, college students' English Language achievement is not ideal. Therefore how to eliminate students' anxiety in English learning is apparently an important project. The teachers teach English, meanwhile, should pay attention to the anxiety of the emotional factors and be fully view the student emotion regulation and inspire their emotional resonance.

\section{REFERENCES}

[1] Horwitz E.K., Horwitz M.B. \& Cope J. Foreign Language Classroom anxiety [J]. Modern Language Journal, 1986, 70(2):125-132.

[2] Macintyre P. D., Gardner R. C. Methods and Results in the Study of Anxiety in Language Learning: A Review of the Literature [J]. Language Learning, 1991, 41:85-117.

[3] Fu Xiaodan. On English Learning Anxiety of College Students under Circumstances of Multimodal Discourse [J]. Journal of Shenyang Institute of Engineering (Social Sciences), 2014(03):370-372

[4] Chen Peng. On English Learning Anxiety of College Students [J]. Journal of Luohe Vocational Technology College, 2009(06):135-136.

[5] Meng Weina. On Foreign Language Learning Anxiety and Innovation Ability Cultivation [J]. Journal of Henan Business College, 2014(04):122-124.

[6] Li Juan. Investigation of English Learning Anxiety of English Majors in higher vocational colleges [J]. Journal of Shanxi Institute of Energy, 2017(03):127-129.

[7] Wu Xianwen. On Language Anxiety and Its Countermeasures in Listening Training of Vocational College English [J]. Journal of Xichang College (Social Science Edition), 2015(04):150-153.

[8] Xia Li, Li yanyan. On English Reading Anxiety of Non-English Majors[J]. Journal of Qiannan Normal College for Nationalities, 2015(03):66-68+89 